\title{
CONDITIONS FOR THE DEVELOPMENT OF TECHNICAL THINKING IN THE LEARNING PROCESS
}

\author{
Mariusz Śniadkowski ${ }^{1}$, Adam Maj² \\ 1 Fundamentals of Technology Faculty, Lublin University of Technology, 38 Nadbystrzycka Str., 20-618 Lublin, \\ Poland, e-mail:m.sniadkowski@pollub.pl \\ 2 The John Paul II Catholic University of Lublin, Al. Racławickie 14, 20-950 Lublin, Poland
}

Received: 2015.01 .15

Accepted: 2015.02.13

Published: 2015.03.01

\begin{abstract}
The technique comes in almost all areas of human life, tying a person inextricably, which requires a change in the concept of the practice of thinking and acting. Thus, forcing a man to actively explore new technologies, equipments, machines, tools and use them in everyday life. It is important that this knowledge is structured, grounded and connected not only with practical action, but with technical thinking, which will allow for the proper functioning of the students in their daily lives. Technical thinking has a conceptually-imaginative nature, and its development is possible when we provide innovative thinking and creative teachers, pay attention to the selection of appropriate tasks and practical actions.
\end{abstract}

Keywords: technical training, technical thinking, technical education.

\section{INTRODUCTION}

In the past, technology was understood as: art, crafts, team work means, the ability, the method of production; and now as a part of the culture and civilization [7]. Now, for the sake of the present discussion we accepted the paradigm of recognizing the primacy of man over technology [3], and the technical education is treated as a "field of universal and compulsory education, which uses the pedagogical qualities of technical activities to support the multilateral development of the psyche of pupils. Technical education is a process of conscious and organized use of information in order to prepare a person to use the information in solving problems arising in the life activity of pupils" [4]. It is generally accepted that information describes the content of a state of things, the phenomenon of the process. However, if we want the indicated task to be accomplished, we need first of all to develop thinking and technical imagination in the educational process.

\section{THE NEED FOR THE TECHNICAL EDUCATION}

The role of the technical education, which is also referred to as: education to technology, technical education, general technical learning, technical classes, etc., is very important. This is because it helps in gaining knowledge of the orientation of the development of technology and it effects on individuals and the society, allows us to pass judgment on the basic principles of the use of technical systems of social interdependencies of their production, use and disposal. The main goal of the general technical education is to assist the student in the process of its development on the basis of values that emphasizes modern technology as a part of human culture [6].

The main tasks of the general education through technology include:

- support and integration of mental, manualmotor and socio-moral of a child, allowing to know and understand himself and his subjectivity in the community and supra; 
- familiarizing pupils with the socio-natural environment, in which technology plays an increasingly important role;

- introducing pupils to the world of human values;

- knowledge and understanding by children and young people the essence and meaning of human work;

- supporting the process of orientation and professional school of students [7].

In the context of the above tasks it can be concluded that it is the "world of technology" can be a tool to support the development of cognitive, emotional and motivational of the student. It is encouraged particularly by the activity of the child, accompanied by continuous contact with the products of technology. The child learns the technique creations and the processes for their formation and gradually begins to understand the nature and value of human labor. On the technical classes the student meets new ,technology language ", i.e. the concepts and names, and begins to use them. The essence of technical education should not only be a transfer of knowledge about the "world of technology", but also supporting a child in a difficult process of learning, developing his technical thinking and interests. The main condition for the effective of the technical education should be the integration of theoretical and practical knowledge of elementary things, actions and phenomena associated with the technique.

The technical education is an activity enabling the student in practical activity associated with thinking. During the activities the student is involved emotionally, and thus shapes the character traits such as: will to act, perseverance, accuracy, saving regularity. The child has the opportunity to develop imagination and practical thinking, exercise efficiency and coordination. Mental activity and focus deepen the knowledge, experience and skills of the student and affects the development of child's personality.

\section{DEVELOPMENT OF INTERESTS AND TECHNICAL SKILLS}

The development of students' interests is influenced by many factors. These include: the age of an individual, their activity, and other environmental impacts [5]. In terms of school education, there are many students with different interests, which are revealed only under appropriate con- ditions. Revealing them is largely determined by such factors as emotions and motivations that are not formed simultaneously with mental dispositions and do not allow students to maximize their abilities. Very often students capabilities' remain undeveloped and unused due to lack of opportunity to disclose.

When we talk about skills, we mean the ability to perform these or other activities, and each ability is the ability to do something, such as: fancy design to construct technical. In the practical activity is the result of a product, a product, a material having some shapes. This also applies to a variety of engineering structures, such as tools, models, machinery, and equipment. In contrast, intellectual activity does not cause direct changes to objects around the human environment. The result of intellectual activity is projects, concepts, which can be then reflected in a specific subject, structure or material. Mental activity in this case is devising and defining the characteristics and properties of the structure, and the need for technical thinking. It can be conscious and purposeful technological activity, mental and practical shapes the structure of individual abilities and technical skills. This could be the ability to design, the ability to perform a particular subject.

Similarly, technical thinking should include the elements of theoretical and practical thinking. "Abilities and technical skills are also called technical imagination it is the fact that a person looks at technical drawing and can mentally imagine how it will look a thing made according to the drawing, what is the ratio of its individual parts" [8]. Technical talent is such a mental property, which allows operation specifications based on the interaction of theoretical thinking with practical action. The result of this activity is the design drawing of a device or equipment or an object. Technical capacity due to its complexity has other components. For inseparable factors demonstrating technical capabilities include interests and skills.

J. Nazar says that the basic forms of education and knowledge dissemination and technical capacity in children and adolescents include:

- trips,

- different types of circles of interest,

- olympics,

- stories about technology and reading technical literature,

- handling-construction plays, 
- competitions,

- practical technical work,

- meetings with rationalizes and inventors [8].

In this regard, training and development of technical skills depend not only on teachers technique, but mainly from students and the environment in which they live. Hence, an important role in shaping technical education is played by technical thinking.

\section{THE SPECIFICITY OF THE TECHNICAL THINKING}

Technical thinking as an intellectual process is indeed the nature of conceptual and imaginative [1]. Ideas are not less important also in other activities, but in technical creativity on the first place there are the logic and the operational requirements (technical) product supply, and the second requirement artistic, aesthetic. Technical ideas cannotarise spontanously in the imagination, survive in the memory and become communicative information without physical counterpart, the media and means of communication, which is a technical drawing. The technical drawing is not just for communication and documentation of technical structures, but is also a necessary means for the development of the technical thoughts and ideas during the manufacturing process.

According to T. Nowacki technical thinking is "a process reflected to the laws of nature in application to the products of technology and production" [9]. Such an understanding of technical thinking recognizes it as a process where we reflect the laws of nature in the products of art with regard to existing creations. It should be noted that technical thinking is not limited only to learning what has already been done in the technique, because there is still a large field of technology production. Technical thinking, it is also "a process of reflecting and applying the laws of nature and the principles of technology in the products of technical and technological processes" [9]. Some of the technical tasks do not link directly to the knowledge of the laws of nature, but require orientation to the rules of art, which are now a reflection of the laws of nature and are included in the material task. Technical thinking consists of the meaning of technical products both in terms used in these laws of nature, as in terms of the rules of the art. Understanding is the hallmark of technical thinking and the guarantor of success in technical action. Consequently, we can distinguish technical thinking - construction (design), and practical thinking - production.

On the basis of the classification of primary sources of information, we can distinguish the following four types of technical thinking:

- practical thinking (or thinking in action);

- graphic thinking, technical drawing (in handling technical drawing);

- imaginative thinking (playback or creating new structures, devising forms of construction);

- conceptual thinking (or theoretical, based on a system of concepts and technical categories, occurring in the planning of activities, explaining, justify) [1].

These types of the technical thinking do not always have to exist as separate categories. They can be combined with each other, or incorporated in another kind of a stage of the process. Thinking is merely a reflex. But the most important question remains how to develop technical thinking in the learning process of pupils?

\section{DEVELOPMENT OF TECHNICAL THINKING IN THE LEARNING PROCESS}

As it has been already indicated the technical thinking, in fact, lies in the meaning of technical products in terms of the rights and principles of art. This understanding is the hallmark of technical thinking and the basis of technical activity. However, it needs to develop technical interests of students, development of imagination and technical skills. In this regard, significant is the role of the teacher, parents, schools and various extracurricular forms of technical education.

\section{Innovations in stimulating of the technical thinking}

Innovations in education arises due to actions, which are defined as the most creative pedagogical, educational progress, innovation" [12]. Pedagogical innovations are understood as "new material or symbolic creations aimed at putting into practice hitherto unknown changes as improvements." Similarly, the issue is recognized by W. Okoń who defines innovation as "any activity aimed deliberately and consciously to introduce changes to the education system in order to improve it" [10]. 
In the literature we can find many different divisions and classifications of innovation, depending on the criteria taken by the individual authors. Due to the taken subject we should pay attention to the division of innovation in a view of the type of innovative solutions. Thus, we can distinguish:

- innovation program - applies any changes to the objectives, content and the required achievements in the field of education,

- methodological innovation - includes any changes made to the way of teaching and relates primarily - technology transfer and enforcement of knowledge in school education,

- technological innovation - includes changes in the use of technological means of education, educational technology,

- organizational innovations - apply to any structural changes defining the functions and roles in the system and organizational-institutional education.

Innovation in a broad sense should be understood as the totality of development activities implemented at all levels of the educational system and multiplying teaching experience. In a narrower sense, you should refer them to the category of innovative activities that are implemented by teachers as direct participants in the educational process [11]. In the first case, creativity is a synonym of teaching pedagogical progress, and consists of all categories of innovation activities carried out within the educational system, namely: planning and implementation of educational reforms, constant updates of the work of school administration, experimental educational institutions and innovation pedagogical introduced by teachers.

The narrow approach is equivalent to the work of teaching with various manifestations of innovation activity of teachers, and so with this type of intentional development that takes place during the direct teaching practice. Entity in this process is the teacher and student, which addressed specific, innovative pedagogical situation. Pedagogical work of teachers is conditional with a creative attitude towards pedagogical understanding and as willingness to solve problems in a professional manner in which effective search of innovative solutions, verification and tendency to scientific modifications [11]. This amounts to the development and use of unconventional methods and forms of teaching, inno- vative teaching aids, scenarios of the original lesson or scientific projects. Here the attitude of the teacher of a lack of template, exploration and improvement of work style, methods of control and evaluation of students' knowledge, innovative way to use teaching aids, students' stimulation of innovation thinking and independence are necessary [13]. The competences necessary to take creative effort is the necessary knowledge, skills and experience backed by an appropriate motivation and responsibility for their actions. The development of students' creative activity largely depends on the creativity of teachers and the methods they use to stimulate technological creativity of students.

\section{Development of thinking through action}

The technical thinking is a cognitive process that leads to a diagnosis of the situation of the task force and to explore the changing conditions of the task in the course of action and focus on a specific purpose, which may be, for example, learning a new machine or only some of its new component, or cognition cause of the malfunctioning [1].

Each practical action is characterized by taking place in direct confrontation with the reality. Acting, student knows and immediately checks the consequences of his actions. Practice is the source of his knowledge and, at the same time, a test of the veracity of the diagnosis and the adequacy of action.

Given the development of the technical thinking, this is done through the development of technical concepts, understanding of technical drawings, disassembly operation, diagnostics, and assembly operations of pupils [1].

Development of technical concepts. Although the technical thinking images of objects, operations, and phenomenon play an important role, it is a basic material is thinking because the thought process is based on the concept. They represent the content of thinking. The content reflects the application of the concepts of natural laws and principles of art creations and practical aspect, functional and usable creations.

Full assimilation of technical concepts can only occur when the imaging layer is illustrated by its referent in the form of a real object or figure, in the theoretical explanation in the operation of the laws of science, and in terms of a usable set used in productive activities or in daily life. 
This multifaceted of technical concepts and the associated complexity process of its development are the two major causes of difficulties in organizational planning teaching techniques and technical education in schools. There is no doubt that knowledge of the structure of the technical terms and conditions their normal development in the teaching and developing students' technical culture cannotbe overlooked.

In terms of the development of technical thinking students must first develop technical concepts, habits and skills to shape slowly, incrementally. This purpose may be served by a notebook with a separate dictionary of concepts and technical terms. We should use the Internet resources and technical literature. Create a thematic newspaper on campus, which students will update and take care.

Understanding of technical drawings. In technique the drawing is considered as a means of communication, without which any technological activity cannot exist. The drawing is an essential means of illustrating technical forms, methods of connection, and details of construction. The drawing on a comp raises adequate ideas and this is its irreplaceable function. Technical drawing is standardized, should be clear, readable. Thus, learning on the basics of technical drawing and its understanding and technical writing is an important task [1]. It is therefore necessary to stimulate students by putting higher and higher requirements towards technical writing exercises by doing activities, notes, homework in technical writing or close to technical writing.

Disassembly activities. Disassembly is opposite to the assembly as practical technical activity. Removal actions are based on the recognition and understanding of structural relationships and dependencies between the elements and principles of operation of the mechanism knowledge. This concerns not only the mechanism as a whole, but also its components. When removing some components not only special tools and auxiliaries are needed, but there is also a need to respect a strict sequence of operational activities. Figuring this order is sometimes very difficult without description. In such cases, you have to guess based on observation of the movement of the external or risk spreading elements that only by mounting attempt to determine the order of receipt of parts into a whole. For these reasons, removal of each mechanism should be generally under special vigilance of student. What matters is not rush, but common sense and logic of the action, not the pace of work, but the method of execution [1].

Technical diagnostics. In various areas the student is faced with the need to seek clarification of the reasons for interruption of a process disturbance or disorder, in order to take decisions to remove undesirable phenomenon and restore order in ensuing state of affairs. Diagnostic problems in the technique are a huge amount, but they have several features in common.

The main goal of any diagnostic procedure is searching the answer to the question "what happened?" In the technology the question is directed to the object (device, mechanism, etc.), it is important to detect and understand causes of the accident, which may have structural causes (damage, mal-performance or installation, fuel, etc.) or functional (friction, overheating, overload, deregulation, etc.). It is important to determine the cause and location of the ailments, what is associated with knowledge construction and operation of the device or object in the operating conditions [1].

In terms of technical diagnostics problems should be put to solve situations by students not only in the classroom, but in relation to the test facility especially for housework. Here, students will explore the causes and possible solutions to technical problems using a variety of sources. Accompanied by parents during their various activities related to the use of tools and equipment.

Assembly operations. Placing sense entirety of the components requires not only the orientation, as to what applied, what then combine and join, but also the participation of thinking, without which the practical operation process disintegrate as successful as the statement of the components is not used as evidence or stages in the directed action. Meaningful action is mounting in its course all the time laced with perceptual activities and thinking. The condition of the successful installation is to understand the meaning and significance of each part as part of a whole and realize functional connections between them [1].

The above mentioned forms are the basis for the development of students' technical thinking . Shaping the technical thinking is a process consisting of different operations. To be effective, this process should have its dynamics. It is indifferent how the student approaches the problem of where to begin, and what will be taken into 
account, how the task will be analyzed, how all the available data will be used to skip elements, etc. Thinking is done in stages, which have their logical order.

\section{Selection of appropriate sentences}

In the current educational situation, the starting point in the activities of education in the development of the technical thinking should be the situations problem, full of new and emerging curiosity and motivation to take technical measures. From the teacher's perspective, it is important to create a climate in the classroom which triggers behavioral and cognitive activity of students, which affects mainly the methods of teaching; participation of students in teaching; preferential attitude and expectations of teachers towards students. Proper climate triggers creative activity in children and motivates to learn technique.

An important role is primarily played by the selection of appropriate technical tasks to individual needs, abilities and talents of students. This task is a structure of the whole which requires the knowledge of individual elements, design, justification of the program, activities and results of the project, they should participate in forming a coherent, logical and specified string factually correct solution. Each task consists of a phase of an investigation into the task; determine the steps leading to the solution, a justified the choice of activities and the determination of the final results. I mean teaching tasks that are associated with the teaching - learning, which the basis of the technical is thinking process of students, such as:

- cognitive tasks - giving the direct learn about technical, undertaken in order to produce theories describing reality or standards of conduct;

- fitness tasks - requiring training, the acquisition of skills in using tools and equipment, materials processing;

- practical tasks - undertaken in order to produce the necessary things and consisting of planning and solving technical issues;

- design task - developing the ability to create the known elements of the new total, combining the work of the mind to manual work.

Content, scope and level of difficulty of the technical tasks should correspond to the capabilities and interests of children taught. Especially technical tasks solved in groups have special educational values. Thanks to the teacher implements the students collaborate and cooperate in a team. Students also learn responsibility.

Here, the task of the school and the teacher is to prepare appropriate material and technical base, so that the student had access to a possibly different materials, interesting information, necessary tools, support, and teaching aids. You can involve the parents or the local business entities.

Speaking of technical developing, students must pass the new knowledge and skills. In addition to the lessons invaluable help is raising the level of reading and literature through appropriate journal subscriptions. We should reach for watching TV shows and technical videos, available as on television and on the Internet. Here you should use students' free time.

The basis of effective technical education is awaken by teachers and parents curious of technical students, by being with children in the presentation of various technical products. In addition, wider involvement of parents is possible, but modestly used.

Therefore, you should strive to create at least one wheel of interests, coinciding with the interest of the teacher or some parents who would be able to spend time in the form of unpaid or voluntary work. In addition, we should increase the number of competitions in class and school of technical issues. You can successfully organize sessions and general technical demonstrations, meetings with persons who do technical activities professionally. Such activities do not require financial expenditures, however, they have an impact on students' interest in technical issues.

\section{CONCLUSION}

Development of the technical thinking of students is one of the objectives in the process of the technical education. Technical training allows teachers to introduce a wide range of creative activities for teaching and learning processes. It cannot be limited only to the tasks of generation, but should pay attention to shaping the attitudes and technical culture including cognitive activity and interests of the students. Proper development of thinking is possible provided by the innovative thinking and creative teachers, who pay attention to the selection of appropriate tasks and making a number of practical measures. This calls for a deeper reflection and theory. 


\section{REFERENCES}

1. Franus E., Myślenie techniczne. WrocławWarszawa- Kraków- Gdańsk 1978.

2. Franus E., Wielkie funkcje technicznego intelektu. Struktura uzdolnień technicznych, Kraków 2000.

3. Furmanek W., Podstawowe założenia nowego modelu polskiej edukacji ogólnotechnicznej w kontekście przemian cywilizacyjnych. [In:] M. Jakowicka, K. Uździcki (eds.) "Edukacja ogólnotechniczna na przełomie XX i XXI wieku”, Kraków 2003.

4. Furmanek W., Jutro edukacji technicznej. Rzeszów 2007.

5. Furmanek W., Walat W., Zarys przewodnika metodycznego dla nauczycieli techniki. Rzeszów 1999.

6. Gawrysiak M., Rola kształcenia ogólnotechnicznego w nabywaniu kwalifikacji kluczowych. [In:]
K. Kraszewski (ed.) "Koncepcja programowa kształcenia ogólnotechnicznego", Kraków 1993.

7. Kraszewski K., Podstawy edukacji ogólnotechnicznej uczniów w młodszym wieku szkolnym. Kraków 2001.

8. Nazar J., Kształtowanie zainteresowań technicznych dzieci i młodzieży. Warszawa 1975.

9. Nowacki T., Podstawy dydaktyki zawodowej. Warszawa 1977.

10. Okoń W., Nowy słownik pedagogiczny. Warszawa 1998.

11. Schulz R., Twórczość pedagogiczna. Warszawa 1994.

12. Schulz R., Studia z innowatyki pedagogicznej. Toruń 1996.

13. Szempruch J., Pedagogiczne kształcenie nauczycieli wobec reformy edukacji w Polsce. Rzeszów 2000 . 